\title{
BANK SYARIAH DAN BANK KONFESIONAL \\ DENGAN NILAI DAN KANDUNGAN TERHADAP \\ PERBEDAAN PENERAPAN DAN \\ PENEGELOLAAN KINERJA KEUANGAN SECARA \\ SYARIAH DAN KONFESIONAL
}

\author{
Jairin \\ Dosen Sekolah Tinggi Ilmu Syariah (STIS) Al-Ittihad Bima \\ Gmail:bangrien@gmail.com
}

\section{Abstrak}

The name of someone, something, institution had a certain meaning. A meaning depended so much on someone's perception to an object. Perception of society to Sharia Bank had an impact to society behavior towa rd Sharia Bank. There was a gap here between bank and society which had to be acted as a bridge through policy and socialization program. Socialization policy which was planned, adaptive, and interesting could minimize the misperception risk. Socially, sosialization program was the enculturization of sharia bank values process, and it was understood as the form of civil education.

Keywords: sharia bank, Confensinal Bank, Diferences rule, performance diference, finanfial performance.

\section{Bank Syariah}

Bank syariah telah tersebar di hampir semua kota di Indonesia. Bahkan bank-bank konvensional juga menyediakan pelayanan bank syariah. Namun mengapa belum banyak masyarakat yang menjadi 
nasabah bank syariah? Secara umum, masyarakat mengenal bank syariah sebagai bank Islam, walau-pun sebenarnya karakter fundamental dari eko-nomi syariah adalah universal dan inklusif.

Prinsip-prinsip syariah menjadi landasan danacuan dalam mengatur hubungan antara perbank-an dan pihak-pihak lain serta di dalam usaha meng-himpun dan menyalurkan dana dan aktivitas per- bankan syariah lainnya. Selain itu dalam opera- sional perbankan syariah pada prinsipnya dapat melakukan kegiatan usaha sepanjang tidak bertentangan dengan petunjuk dan ketentuan syariah, peraturan perundangundangan yang berlaku serta persetujuan Bank Indonesia dan Dewan Syariah Nasional.

Namun pada kenyataannya, seringkali ter-jadi pemahaman yang berbeda baik dari kalangan internal pemeluk agama Islam maupun masyarakatpada umumnya. Kesalahpahaman tersebut dise- babkan oleh ketidaktahuan masyarakat terhadap hakikat dan berbagai bentuk pelayanan bank syariah. Sebagai contoh, penolakan dari Partai Damai Sejahtera (PDS) saat pembahasan Rancangan Undang-undang Perbankan Syariah dan Undang- undang Surat Berharga Syariah Negara (SBSN). Kesalahpahaman di awal perkenalan membawa pengaruh pada hubungan selanjutnya, antara lain terkatung-katungnya proses pengesahan kedua RUU tersebut sehingga memakan waktu yang cu- kup lama (Agustianto, 2008). 
Demikian juga hasil penelitian KARIM Busi- ness Consulting (2004) dalam Sholihin (2011) me- nunjukkan bahwa kurangnya promosi maupun edukasi pasar menyebabkan masyarakat kurang mengetahui bank syariah, baik mengenai hakikat, produk maupun fasilitas yang ditawarkan.

Hal ini juga ditemukan pada saat wawancara penulis dengan beberapa informan (masya- rakat) yang terdiri atas pegawai, petani, pedagang, guru, dan mahasiswa. Pendapat masyarakat me- nunjukkan bahwa nama bank syariah membentuk sebuah gambaran atau citra bank yang identik de-ngan agama Islam. Hampir tidak terdengar ko- mentar masyarakat bahwa bank syariah adalah se-buah sistem perbankan yang adil, manusiawi, memiliki nilai spiritual, handal, berteknologi canggih.

Hasil penelitian Puspitaningsih (2009) me- nunjukkan bahwa untuk persepsi dan pemahaman masyarakat terhadap bank syariah, penerapan bank syariah sebagai alternatif untuk membangun per- ekonomian Indonesia khususnya untuk jasa tran- saksi keuangan umat muslim, sebagai penerapan Islam secara utuh baik secara aqidah dan muamalahnya, masih memerlukan pengenalan yang lebih intensif. Hal ini dikarenakan regulasi perbankan syariah di Indonesia masih relatif baru.

Demikian pun salah satu saran dari hasil penelitian Fatmah (2008) mengenai perilaku kon- sumen muslim (religious motive dan 
economic motive dalam proses pengambilan keputusan) adalah melaksanakan sosialisasi dan promosi secara lebihintensif yang bertujuan untuk memberikan infor- masi yang lengkap dan benar mengenai kegiatan usaha perbankan syariah kepada masyarakat).

Beberapa hasil dan rekomendasi penelitian terdahulu mengenai bank syariah mendorong ka- jian mengenai sosialisasi dan persepsi masyarakatterhadap bank syariah yang ditinjau dari kajian kebijakan enkulturasi nilai-nilai bank syariah dalammasyarakat. Dasar pemikiran kajian ini, pertama adalah pluralitas masyarakat Indonesia merupakan sebuah entitas yang tidak menafikkan bahwa sebagian be- sar masyarakatnya memeluk agama Islam, ter- masuk di Kota Malang. Kedua, Pancasila sebagai dasar negara Indonesia telah menjadi jaminan tum- buh kembangnya sikap toleransi di antara umat beragama sebagai komunitas inklusif yang tidakdibatasi oleh sikap eksklusifisme berdasarkan sen-timen keagamaan, termasuk dalam hal memilih bank. Ketiga, karakter dasar ekonomi syariah ialah sifatnya yang universal dan inklusif.

Ekonomi syariah mengajarkan tegaknya nilai-nilai keadilan, kejujuran, transparansi, anti korupsi, dan eksploitasi. Artinya misi utama ekonomi syariah adalah tegak- nya nilai-nilai akhlak moral dalam aktivitas bisnis, baik individu, perusahaan ataupun negara. Karena itu, proses enkulturasi nilai-nilai bank syariah melalui program sosialisasi 
yang terencana, adaptifdan menarik dapat meminimalisir risiko misperception. Selanjutnya persepsi positif masyarakat ter-hadap bank syariah dapat membentuk citra positif dan mendorong peningkatan jumlah nasabah.

Harapannya, semakin banyak masyarakat yang menjadi nasabah bank syariah maka nilai-nilai akhlak moral memberi warna dalam aktivitas bisnis, baik individu, perusahaan ataupun negara, sehingga tercipta masyarakat Indonesia yang men-junjung tinggi nilai-nilai keadilan, kejujuran, trans-paransi, anti korupsi, dan eksploitasi.

\section{Hakikat dan Fungsi Bank Syariah}

Bank syariah adalah bank yang beroperasisesuai dengan prinsipprinsip syariah Islam, atau mengacu pada ketentuan-ketentuan Al-Qur'an dan Hadist (Perwataatmaja \& Antonio, 1999). Fungsi bank syariah adalah sebagai: manajer inves-tasi, investor, penyedia jasa keuangan dan lalu lin-tas pembayaran, dan pengemban fungsi sosial (PAPSI, 2003). Sedangkan jenis-jenis produk bank syariah, adalah titipan (wadi'ah yad al-amanah dan Kridawati Sadhana wadi'ah yad adh-dhamanah); produk bagi hasil(mudharabah, musyarakah, muzara'ah, dan musaqah); jual-beli (bai' al-murabahah, bai' as-salam, dan ai' al-istishna); sewa (al-ijarah, al-ijarah almuntahia bit-tamlik); jasa (al-wakalah, al-kafalah, al-hawalah, ar rahn, dan alqardh).

Sangaji Jurnal Pemikiran Syariah dan Hukum 


\section{Konsep Bagi Hasil}

Bagi hasil adalah suatu sistem yang meliputi tata cara pembagian hasil usaha antara penyedia dana dan pengelola dana. Pembagian hasil usaha ini dapat terjadi antara bank dengan penyimpan dana, maupun antara bank dengan nasabah pene-rima dana. Pada prinsipnya referensi perhitungan bagi hasil adalah dari seluruh pendapatan yang diperoleh bank dalam menjalankan usahanya, yang kemudian dibagikan kepada pemilik dana se-suai dengan porsi yang disepakati. Konsep bagi hasil ini dapat dilakukan dengan menggunakan dua metode yaitu bagi laba (profit sharing) atau bagipendapatan (revenue sharing).

Pada tataran pemahaman calon nasabah ter-hadap bank syariah dapat dibantu dengan teori preferensi dan pilihan konsumen. Sebab sangat penting membentuk persepsi masyarakat berda- sarkan informasi seluas-luasnya tentang bank sya- riah. Menurut teori preferensi dan pilihan kon- sumen, bahwa seorang konsumen dalam membuat keputusan terhadap apa yang ingin dibelinya me- lalui beberapa proses, yaitu proses pengenalan ke- butuhan, pencarian informasi, evaluasi alternatif, proses pembelian dan perilaku pasca pembelian(Engel, et al, 1994, dalam Aiyub, 2007). Sebab proses awal dalam tahapan pengambilan keputus-an adalah seseorang atau sekelompok orang berusaha mencari tahu tentang manfaat dari produk atau jenis pelayanan yang ditawarkan. 
Tabel 1. Perbedaan Bunga dan Bagi Hasil

\begin{tabular}{|c|c|c|}
\hline Bunga & $\begin{array}{l}\text { Indikator } \\
\text { perbedaan }\end{array}$ & Bagi Hasil \\
\hline $\begin{array}{l}\text { Penentuan bunga } \\
\text { dibuat pada waktu akad } \\
\text { dengan asumsi harus } \\
\text { selalu untung }\end{array}$ & $\begin{array}{c}\text { Waktu } \\
\text { penentuan }\end{array}$ & $\begin{array}{l}\text { Penentuan } \\
\text { rasio/nisbah bagi hasil dibuat } \\
\text { pada waktu akad dengan } \\
\text { berpedoman }\end{array}$ \\
\hline $\begin{array}{l}\text { Besarnya prosentase } \\
\text { berdasarkan pada jumlah } \\
\text { uang (modal) yang } \\
\text { dipinjamkan } \\
\text { Pembayaran bunga tetap } \\
\text { seperti yang dijanjikan } \\
\text { tanpa pertimbang- an } \\
\text { apakah proyek yang } \\
\text { dijalankan oleh nasabah } \\
\text { untung atau rugi }\end{array}$ & Persentase & $\begin{array}{l}\text { Besarnya rasio bagi hasil } \\
\text { berdasarkan pada jumlah } \\
\text { keuntungan yang diperoleh Bagi } \\
\text { hasil tergantung } \\
\text { keuntungan proyek yang } \\
\text { dijalankan. Bila usaha merugi, } \\
\text { kerugian akan ditanggung } \\
\text { bersama oleh ke- dua belah } \\
\text { pihak }\end{array}$ \\
\hline $\begin{array}{l}\text { Jumlah pembayaran } \\
\text { bunga tidak meningkat } \\
\text { sekalipun jumlah keun- } \\
\text { tungan berlipat atau }\end{array}$ & Ukuran /standar & $\begin{array}{l}\text { Jumlah pembagian laba } \\
\text { meningkat sesuai dengan } \\
\text { peningkatan jumlah pendapatan. }\end{array}$ \\
\hline
\end{tabular}

Sangaji Jurnal Pemikiran Syariah dan Hukum 


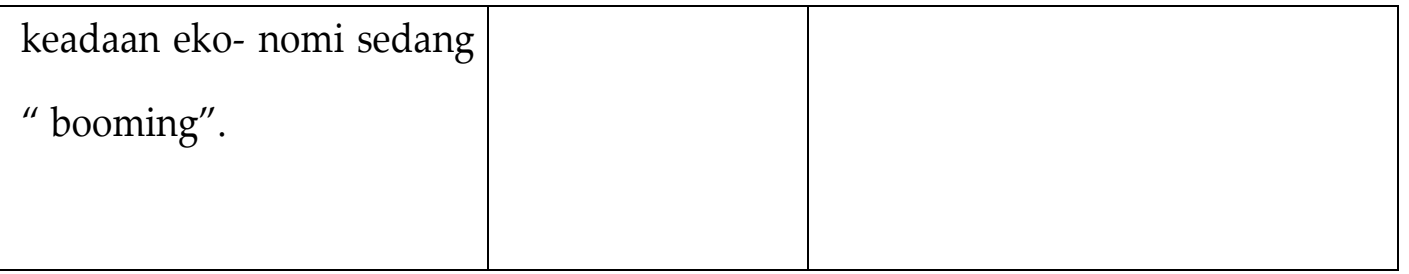

\section{Bagi Hasil}

Penentuan bunga dibuat padawaktu akad dengan asumsi harus selalu untung Waktu penentuanPenentuan besarnya rasio/nisbah bagi hasil dibuat pada waktu akad dengan berpedoman pada kemungkinan untung danrugi

Besarnya prosentase berdasarkan pada jumlah uang (modal) yang dipinjamkan Pembayaran bunga tetap seperti yang dijanjikan tanpa pertimbang- an apakah proyek yang dijalankanPersentase Besarnya rasio bagi hasil berdasarkan padajumlah keuntungan yang diperoleh.

Bagi hasil tergantung pada keuntungan proyek yang dijalankan. Bila usaha merugi,kerugian akan ditanggung bersama oleh ke-oleh nasabah untung atau rugi Ukuran standar Jumlah pembayaran bunga tidak meningkat sekalipun jumlah keun- tungan berlipat atau keadaan eko- nomi sedang " booming". dua belah pihak. Jumlah pembagian laba meningkat sesuaidengan peningkatan jumlah pendapatan.

Eksistensi bunga diragukan (kalau tidak dikecam) oleh semua agama termasuk Islam. Tingkat kepercayaanTidak ada yang meragukan keabsahan bagihasil. kenali alasan dan motivasi mengapa 
tertarik dan melibatkan diri dalam hal tersebut). Jika calon kon-sumen atau nasabah sudah mulai tertarik, maka proses selanjutnya konsumen pasti berusaha men- dapatkan informasi yang lebih rinci mengenai produk tersebut melalui media-media informasi yang menginformasikan tentang produk tersebut, misal-nya media cetak atau media elektronik. Satu halyang tidak kalah pentingnya dalam proses ini ada-lah referensi dari pemakai/nasabah, tokoh masya-rakat atau ulama, atau masyarakat lainnya yangterpercaya.

Berdasarkan berbagai referensi tersebut, se-orang calon konsumen melakukan evaluasi alter- natif yang menjadi pertimbangan awal bagi kon- sumen untuk mendapatkan produk tersebut. Ter- masuk dalam pertimbangan pada tahap ini adalah mengenai harga, mutu atau merk dan keunggulan- keunggulan yang dimiliki oleh barang tersebut dibandingkan dengan barang lainnya. Setelah mempertimbangkan semuanya, maka selanjutnya adalah proses pengambilan keputusan yaitu membeli atau tidak barang tersebut. Jika akhirnya konsumen memutuskan untuk membeli maka hal penting yang perlu diketahui adalah perilaku kon-sumen pascapembelian, artinya mengukur sejauhmana konsumen merasa puas terhadap apa yang dibelinya. Karena faktor kepuasan menentukan pembuatan keputusan berikutnya.

Faktor-faktor tersebut juga dikenal dalam pembahasan kebijakan publik sebagai tahapan pengambilan keputusan oleh policy 
maker atau state. Sehingga menurut Dye (dalam Islamy, 2001), kebi-jakan publik adalah " is whatever governments choose to do or not to do ." Acuan sekaligus tujuan pilihan pemerintah sebagai penyedia layanan adalah kepuasan konsumen (baca: masyarakat). Karena itu, implementasi setiap kebijakan publik selaludiikuti dengan evaluasi terhadap dampak kebijak- an bagi masyarakat. Setiap tahapan tersebut dila- kukan dan atau dipilih dengan memperhitungkan dinamika tuntutan dan kebutuhan masyarakat. Pada konteks pembahasan ini, negara juga turutberperan serta dalam memasyarakatkan nilai-nilai bank syariah.

Sebab jika menoleh pada hasil penelitian Hamidi, dkk (2007) mengenai persepsi dan sikap masyarakat santri Jawa Timur terhadap bank syariah bahwa kenyataan mayoritas masyarakat Indonesia adalah muslim, dan 54\% secara fighiyah tidak menyetujui bunga bank, namun dalam prak-tiknya bentuk kegiatan usaha, produk, dan jasa perbankan syariah (yang secara konseptual tidakberdasar pada bunga kurang dimengerti oleh masyarakat, yang menyebabkan kurangnya minat masyarakat untuk menggunakan bank syariah), se-hingga selama 10 tahun total pangsa pasar bank ataupun institusi syariah baru mampu mencapaisekitar 1\% dari pangsa pasar bank secara nasional.

Bahkan market share bank syariah pada tahun 2010 hanya di bawah $5 \%$ dari total aset perbankan nasional (Arim, 2010). Hal ini mengindikasikan pe- mahaman nasabah belum betul-betul dilaksanakan 
atau diyakini sebagai prinsip hidup. Prinsip-prinsip syariah walaupun sudah dipahami, namun belum terinternalisasi dalam perilaku.

Suatu aksioma bahwa masyarakat Jawa Timur adalah masyarakat santri (daerah tapal kuda/ pesantren) yang memegang teguh nilai-nilai aga- ma, dan dipraktikkan dalam seluruh aktivitas kehidupan. Namun di Jawa Timur kehadiran bank syariah belum sepenuhnya mendapat sambutandari masyarakat santri. Kenyataan ini juga meru- pakan salah satu temuan dari penelitian Hamidi,dkk. (2007) bahwa masyarakat Jawa Timur belum mengoptimalkan keberadaan jasa dan layanan per-bankan syariah, bukan hanya karena keberadaanbank syariah belum merata di Jawa Timur, tetapi sekaligus bukti bahwa faktor agama bukan menjadi faktor utama dalam memilih bank.

Berbeda dengan hasil penelitian tersebut, penelitian Fatmah (2008) mengenai perilaku konsu-men muslim (religious motive dan economic motive dalam proses pengambilan keputusan), menyim-pulkan bahwa penyebab nasabah tetap loyal pada bank syariah adalah ketaatan mereka terhadap sya- riah (religious motive ), economic motive, kepercayaan, dan komitmen.

Hal ini menunjukkan bahwa penilaian atas baik buruknya kebenaran penerapan nilai-nilai Islam dalam operasional perbankan syariah akan memiliki pengaruh besar terhadap loyalitas kon- sumen (masyarakat) terhadap bank syariah. De- ngan kata lain, kualitas 
penerapan nilai-nilai Islam di bank syariah menjadi jaminan daya tarik seka- ligus daya ikat loyalitas konsumen. Karena itu sum-ber daya manusia perbankan syariah harus mampu mengimplementasi prinsip syariah dalam praktik perbankan, serta mempunyai komitmen kuat untuk menerapkan secara konsisten. Artinya, kualitas pe-layanan dan nilai-nilai religiusitas merupakan fak-tor kunci kesuksesan perbankan syariah.

Penekanan pada nilai-nilai yang dimaksud- kan disini adalah sesuai karakter fundamental eko-nomi syariah yaitu universal dan inklusif; dan sis- tem perbankan yang adil, manusiawi, memiliki nilaispiritual, handal, berteknologi canggih.

\section{Persepsi tentang Bank Syariah}

Persepsi adalah proses yang dipakai individu mengelola dan menafsirkan kesan yang ditangkap indera seseorang dalam rangka memberikan mak-na kepada sesuatu obyek (lingkungan, orang, benda, dan lain sebagainya). Namun seringkali apa yang dipersepsikan seseorang dapat berbeda dari kenyataan yang obyektif (Robbins, 1996). Menurut Daviddof (1991), persepsi adalah proses yang di- lalui oleh suatu stimulus yang diterima panca indera yang kemudian diorganisasikan dan diinterpreta- sikan sehingga individu menyadari yang diinde-ranyaitu. Sedangkan Atkinson, et al. (1999) menga- takan bahwa persepsi adalah proses dimana kitamenafsirkan dan mengorganisasikan pola stimu- lus dalam lingkungan. 
Persepsi juga dilihat sebagai cara pandang yang timbul karena adanya respon terhadap stimulus. Stimulus yang diterima seseorang sangat kompleks, stimulus masuk ke dalam otak (melalui syaraf sensorik motorik), kemudian diartikan, di- tafsirkan serta diberi makna melalui proses yang rumit baru kemudian dihasilkan persepsi (Atkinson, et al., 1999). Menurut Walgito ( 2002), proses ter- jadinya persepsi tergantung dari pengalaman masa lalu dan pendidikan yang diperoleh individu. Dengan demikian, stimulus yang diterima sese-orang masuk melalui syaraf sensorik motorik lalu bertemu dengan apersepsi atau pengetahuan dan pengalaman terdahulu yang telah diterima sese-orang dan telah berbentuk kesan, kemudian di-interpretasikan dan menghasilkan suatu kesan yangbaru.

Beberapa faktor yang perlu diperhatikan agarstimulus masuk dalam rentang perhatian seseorang(Notoatmodjo, 2005), diklasifikasikan atas dua ba- gian besar yaitu faktor eksternal (faktor yang me- lekat pada objeknya) dan faktor internal (faktor yang terdapat pada orang yang mempersepsikanstimulus tersebut): (1) Faktor Eksternal, yang me- liputi: (a) Kontras. Cara termudah dalam menarik perhatian adalah dengan membuat kontras baik warna, ukuran, bentuk atau gerakan. (b) Perubahan Intensitas. Suara yang berubah dari pelan menjadi keras, atau cahaya yang berubah dengan intensitas tinggi akan menarik perhatian seseorang. (c) Pengulangan (repetition). Dengan pengulangan, walaupun 
pada mulanya stimulus tersebut tidak termasuk dalam rentang perhatian kita, maka akan mendapat perhatian kita. (d) Sesuatu yang baru (novelty). Suatu stimulus yang baru akan lebih menarik perhatian kita daripada sesuatu yang telah kita ketahui. Contoh nama bankmenggunakan kata bahasa Arab "Bank Syariah". (e) Sesuatu yang menjadi perhatian orang banyak.

Suatu stimulus yang menjadi perhatian orang banyak akan menarik perhatian seseorang. (2) Faktor Internal. (a) Pengalaman atau pengetahuan. Pengalaman atau pengetahuan yang dimiliki seseorang merupakan faktor yang sangat berperan dalam menginterpretasikan stimulus yang diterima. Pengalaman masa lalu atau apa yang telah dipelajari akan menyebabkan terjadinya perbedaan interpretasi. Dalam hal ini, nilai-nilai religiusitas akan berpengaruh terhadap keputusan seseorang. (b) Harapan (expectation). Harapan terhadap sesuatu akan memengaruhi persepsi terhadap stimulus. (c) Kebutuhan. Kebutuhan akan menyebabkan sese- orang menginterpretasikan stimulus secara berbeda. Misalnya seseorang yang mendapat hadiah undian sebuah sepeda motor akan merasa kesulitan atau kebingungan sebab yang bersangkutan belum bisa mengendarainya. (d) Motivasi. Orang yang berpendapat menabung adalah jaminan hidup maka ia termotivasi untuk menyimpan uangnya di bank. (e) Emosi. Emosi memengaruhi persepsi seseorang terhadap stimulus yang ada. (f) Budaya. Faktor budaya juga 
memengaruhi persepsi seseorang ter-hadap suatu objek. Misalnya: memberi dengan tangankiri dipersepsikan tidak sopan dalam budaya In-donesia, sedangkan negara-negara lain tidak mem- persoalkan kiri dan kanan dalam memberi.

Jadi, persepsi adalah proses seorang individu memilih, mengorganisir, menginterprestasi masukan-masukan informasi untuk menciptakan gambaran yang memiliki makna atau arti tertentu. Kemudian, berdasarkan faktor yang memengaruhi persepsi seseorang maka dapat dipahami bahwa perbedaan persepsi antara individu bisa disebabkan oleh adanya perbedaan daya tangkap, tahap kecerdasan serta harapan-harapan yang ada pada masing-masing individu.

Kajian mengenai faktor-faktor yang memenga-ruhi persepsi di atas membantu para pengambilkebijakan perbankan syariah bahwa 'nama bank'dengan kata bahasa Arab "syariah" memunculkan motivasi religius yang sangat efektif untuk mena- rik masyarakat menjadi nasabah bank syariah. Namun ini hanya sebagai langkah awal, sebab fak-tor lain yang harus diperhatikan adalah faktor ha- rapan nasabah. Karena itu, pihak bank harus mampu ntuk memenuhi preferensi dan harapan na-sabah. Dengan kata lain, loyalitas nasabah terhadap bank syariah tergantung pada kemampuan untuk memenuhi harapan nasabahnya tidak hanya darisisi agama (religious motive) tetapi juga dari sisi eko-nomi (economic motive).

Sangaji Jurnal Pemikiran Syariah dan Hukum 


\section{Sosialisasi: Proses Enkulturasi Nilai-nilaiSyariah}

Berbagai penelitian terdahulu menunjukkan bahwa persepsi masyarakat terhadap nama bank syariah sangat kuat dipengaruhi oleh konsep ajaran agama Islam. Nama bank syariah berpengaruh terhadap pandangan masyarakat mengenai eksistensi dan model/sistem pelayanan bank, sekaligus menumbuhkan harapan dan kepercayaan. Hanya sedikit yang memahami nilai universalisme dan inklusifitas bank syariah.

Sebab berdasarkan kajian dan analisis dari beberapa penelitian terdahulu dan wawancara de- ngan beberapa masyarakat di Kota Malang, terlihat bahwa pengetahuan masyarakat tentang bank syariah sangat terbatas, yaitu: (1) Bank syariah adalah bank Islam. (2) Ada sebagian masyarakat yang pernah mendengar namanya saja. (3) Kebanyakan masyarakat tahu bank syariah dari media massa dan dari rekan atau masyarakat lain. (4) Pengetahuan mengenai sistem manajemen dan produk pelayanan bank syariah juga masih rendah. (5) Konsepyang sering dibicarakan adalah "penolakan riba" danpenerapan sistem bagi hasil.

Terbatasnya pengetahuan masyarakat terhadap bank syariah melahirkan persepsi yang keliru dan berdampak pada rendahnya keputusan masyarakat untuk memilih bank syariah. Hal ini tidak saja menghambat ekspansi pasar bank syariah tetapi juga menghambat penyebaran nilai-nilai universal. Untuk itu sosialisasi secara 
konsekutif harus dilakukan, didukung oleh komitmen kuat dari seluruh sumber daya manusia bank syariah untuk mengimplementasikan prinsip syariah dalam keseluruhan praktik perbankan.

\section{Penutup}

Sosialisasi terencana, adaptif dan menarik perlu dilakukan secara kontinyu dan efektif baik melalui media elektronik, media cetak, maupun kelompok elite (pemerintah, tokoh agama dan to- koh masyarakat) untuk meningkatkan pengetahu- an dan pemahaman masyarakat terhadap bank syariah. Sosialisasi yang efektif dan intensif perlu ditekankan pada hakikat bank syariah terutama prinsip-prinsip universalisalitas dan inklusifitas perbankan syariah, aspek keunggulan komparatif bank syariah, serta produk dan jasa yang dimiliki oleh Bank Syariah. Sebab ekonomi syariah bukanlah ajaran agama tertentu, tetapi adalah nilai-nilai ke- adilan, kejujuran, tranparansi, tanggung jawab, yang menjadi nilai-nilai universal bagi semua orang. Nilai-nilai itu berasal dari Al-Qur'an dan Hadits.

Dengan demikian, sosialisasi tidak saja bertu- juan untuk meminimalisir risiko misperception, tetapi sebagai proses penanaman (enkulturasi) nilai-nilaibank syariah dan atau dipahami sebagai bentuk civil education. Dengan kata lain, persepsi awal masyarakat yang 
cenderung melihat bank syariah sebagai bank konvensional yang menggunakan istilah Arab untuk nama produknya pasti berubah dengan sendirinya. Sehingga pada akhirnya, se- makin banyak masyarakat yang menjadi nasabah bank syariah maka nilai-nilai akhlak moral mem- beri warna dalam aktivitas bisnis, baik individu, perusahaan ataupun negara, sehingga tercipta masyarakat Indonesia yang menjunjung tinggi nilai-nilai keadilan, kejujuran, transparansi, antikorupsi, dan eksploitasi. 


\section{DAFTAR PUSTAKA}

Agustianto. 2008. Ekonomi Syariah Untuk Kemaslahatan Bangsa. http://www.pesantrenvirtual.com/

index.php?option=com_content\&view=article\&id $=\quad$ 1206:ekonomisyariah-untuk-kemaslahatan- bangsa\&catid=8:kajian-ekonomi\& Itemid=60 (Diakses tanggal 7 November 2012).

Aiyub. 2007. Analisis Perilaku Masyarakat terhadap Keinginan Menabung dan Memperoleh Pembiayaan pada Bank Syariah di Nanggroe AcehDarussalam. Jurnal Manajemen Bisnis , 8(1): 1-4.

Antonio, M.S. 2001. Bank Syariah: Dari Teori ke Praktik.

Jakarta: Gema Insani.

Atkinson, R.L., Atkinson, R.C., \& Hilgard, E.R. 1999. Pengantar Psikologi. Edisi 8. Jilid 2. Jakarta: Penerbit Erlangga.

Davidoff, L.L. 1991. Psikologi Suatu Pengantar . Jakarta: Erlangga

Fatmah. 2008. Perilaku Konsumen Muslim (Religious Mo- tive dan Economic Motive dalam Proses Pengambilan Keputusan. Fakultas Ekonomi Universitas Muhammadiyah, Surabaya. http://fatmahazis. files.wordpress.com. (Diakses tanggal 31 Oktober2012).

Hamidi, J., Hamidah, S., Sukarmi, Sihabuddin, Hendrawati, L., \& Kusumaningrum, A. 2007. Persepsi dan Sikap Masyarakat Santri Jawa Timur terhadap Bank Syariah. Jurnal Keuangan dan Perbankan, XI(3).

Islamy, M.I. 2001. Policy Analysis, Seri Monografi Kebijakan Publik. Malang:

Universitas Brawijaya,

Machmud, A. \& Rukmana. 2010. Bank Syariah - Teori, Kebijakan, dan

Studi Empiris di Indonesia. Jakarta:Erlangga.

Naz'aina. 2007. Hubungan Tingkat Kesehatan Bank Umum Syariah dengan Pertumbuhannya. JurnalManajemen Bisnis, 8(1): 66-83.

Notoatmodjo, S. 2005. Promosi Kesehatan Teori dan Aplikasi . 
Cetakan I. Jakarta: PT.Rineka Cipta.

Perwataatmaja, K. \& Antonio, S. 1999. Apa dan Bagaimana Bank Islam. Yogyakarta: PT.Dana Bhakti Prima Yasa.

Puspitaningsih, D. 2009. Analisis Aplikasi Prinsip- prinsip Perbankan Syariah terhadap Aspek Penghimpunan Dana dan Aspek Penyaluran Dana (Studi Kasus pada Bank Muamalat Indone-sia Cabang Malang). Skripsi . (Tidak Dipubli- kasikan). Fakultas Ekonomi Universitas Negeri Malang. 